\title{
Review of genus Afrikanetz Yakovlev, 2009 (Lepidoptera: Cossidae) with descriptions of four new species and establishment of new combination for Coryphodema zimbabwensis Mey, 2017 and Camellocossus austrorum Mey, 2017
}

\author{
Обзор рода Afrikanetz Yakovlev, 2009 (Lepidoptera: Cossidae) с \\ описанием четырёх новых видов и установлением новых \\ комбинаций дия Coryphodema zimbabwensis Mey, 2017 и \\ Camellocossus austrorum Mey, 2017
}

\author{
R.V. Yakovlev ${ }^{1,2}$, Th. Witt ${ }^{3,4}$ \\ P.В. Яковлев ${ }^{1,2}$, Т. Витт ${ }^{3,4}$
}

\footnotetext{
${ }^{1}$ Altai State University, Lenina pr. 61, RF-656049 Barnaul, Russia.

${ }^{2}$ Tomsk State University, Laboratory of Biodiversity and Ecology, Lenina pr. 36, 634050 Tomsk, Russia. E-mail: yakovlev_asu@mail.ru

${ }^{3}$ Museum Witt, Tengstrasse 33, D-80796 Munich, Germany.

${ }^{4}$ Ludwig-Maximilians-Universität München, Geschwister-Scholl-Platz 1, 80539 München, Germany.

${ }^{1}$ Алтайский государственный университет, пр. Ленина 61, Барнаул, 656049, Россия.

2 Томский государственный университет, Лаборатория биоразнообразия и экологии, пр. Ленина 36, Томск 634050, Россия.
}

KEY WORDS. Cossidae, Afrotropical Region, new species, Kenya, Tanzania, Uganda, Guinea Equatorial, fauna, taxonomy.

КЛЮЧЕВЫЕ СЛОВА.Cossidae, Афротропический регион, новые виды, Кения, Танзания, Уганда, Экваториальная Гвинея, фауна, таксономия.

ABSTRACT. The article gives an illustrated catalog of the genus Afrikanetz Yakovlev, 2009 (Lepidoptera, Cossidae), including nine species. New combinations, Afrikanetz zimbabwensis (Mey, 2017) comb.n. and Afrikanetz austrorum (Mey, 2017) comb.n. are given. The study also describes four new species: Afrikanetz dargei Yakovlev, sp.n. from Tanzania, Afrikanetz hoppei Yakovlev, sp.n. from Equatorial Guinea, Afrikanetz ugandensis, Yakovlev sp.n. from Uganda, and Afrikanetz witti Yakovlev, sp.n. from Kenya. The distribution map and descriptions of female genitalia (A. ugandensis) are given for the first time.

РЕЗЮМЕ. Приводится иллюстрированный каталог рода Afrikanetz Yakovlev, 2009 (Lepidoptera: Cossidae), включающий девять видов. Установлены новые комбинации: Afrikanetz zimbabwensis (Mey, 2017) comb.n. и Afrikanetz austrorum (Mey, 2017) comb.n. Описывается четыре новых вида: Afrikanetz dargei Yakovlev, sp.n. из Танзании, Afrikanetz hoppei Yakovlev, sp.n. из Экваториальной Гвинеи, Afrikanetz ugandensis Yakovlev, sp.n. из Уганды и Afrikanetz witti Yakovlev, sp.n. из Кении. Дана карта распространения рода. Впервые описаны гениталии самки A. ugandensis.

Carpenter moths (Lepidoptera: Cossidae) are a relatively small family of ditrisyan Lepidoptera including over 1000 species. About 200 valid taxa are known from Afrotropics [Yakovlev, 2011]. Cossidae of the Afrotropical region are studied very fragmentary. There are some published reviews, claiming to be complete, on the fauna of Zimbabwe [Yakovlev, Lenz, 2013], Malawi [Yakovlev, Murphy, 2013], Zambia [Yakovlev, 2014], Swaziland [Yakovlev, Witt, 2016], Burundi [Yakovlev, Witt, 2019], and the detailed revision of South African Cossidae [Mey, 2015, 2016, 2017]. Also, in the recent years new taxa have been described from Cameroon, Kenya, Ethiopia and the Republic of South Africa [Yakovlev, Sáfián, 2016; Yakovlev, Witt, 2017].

The genus Afrikanetz was established by me (from the original description) for A. inkubu Yakovlev, 2009. In addition to the type species, A. bugvan Yakovlev, 2009 and $A$. makumazan Yakovlev, 2009 were included

How to cite this article: Yakovlev R.V., Witt Th. 2019. Review of genus Afrikanetz Yakovlev, 2009 (Lepidoptera: Cossidae) with descriptions of four new species and establishment of new combination for Coryphodema zimbabwensis Mey, 2017 and Camellocossus austrorum Mey, 2017 // Russian Entomol. J. Vol.28. No.3. P.317-322. doi: 10.15298/rusentj.28.3.11 
into the genus. The autapomorphical characters of the genus are: the black stroke on the fore wing in discal area, and the ribs on the inner surface of the costal edge of the valve [Yakovlev, 2009].

The genus Afrikanetz is widely spread in Africa (Fig. 1). As some other African genera of Cossidae (e.g., Afroarabiella Yakovlev, 2008, Camellocossus Yakovlev, 2011, Aethalopteryx Schoorl, 1990), it mostly inhabits semi-deserts and savannas, in the north reaches Arabia [Yakovlev, Dubatolov, 2013].

\section{Materials and methods}

The materials for this study were examined in the following depositories: Natural History Museum (NHMUK, London); Museum Witt (MWM, Munich, later in Zoologische Sammlung der Bayerischen Staates (ZSM), Ditsong Museum of Natural History (TMSA, Pretoria), Museum für Naturkunde, Leibniz Institut für
Evolution und Biodiversitatsforschung) (MNKB, Berlin), Natural History Museum of Zimbabwe (NHMZ, Bulawayo) and private collection of Manfred Ströhle (MSW, Weiden). The permanent genital preparations were made according to the standard methods on slides in euparal, tinted with eosin. The images were processed in CorelDraw 2017.

\section{Results}

Description of new species Afrikanetz dargei Yakovlev, sp.n.

Figs 2, 12.

MATERIAL. Holotype $\sigma^{\top}$, Tanzanie, Arusha Region, Mt. Meru, Campsite 3, $1680 \mathrm{~m}, 20.10 .2004,03^{\circ} 14.684^{\prime} \mathrm{S} / 36^{\circ} 50.626^{\prime} \mathrm{E}$, leg. Ph. Darge (MWM, GenPr Heterocera MWM: 32.862).

DESCRIPTION. Male. Length of fore wing $12 \mathrm{~mm}$. Antenna bipectinate. Crest processes 4 times longer than antenna rod diameter. Tegulae and patagia pale grey. Fore

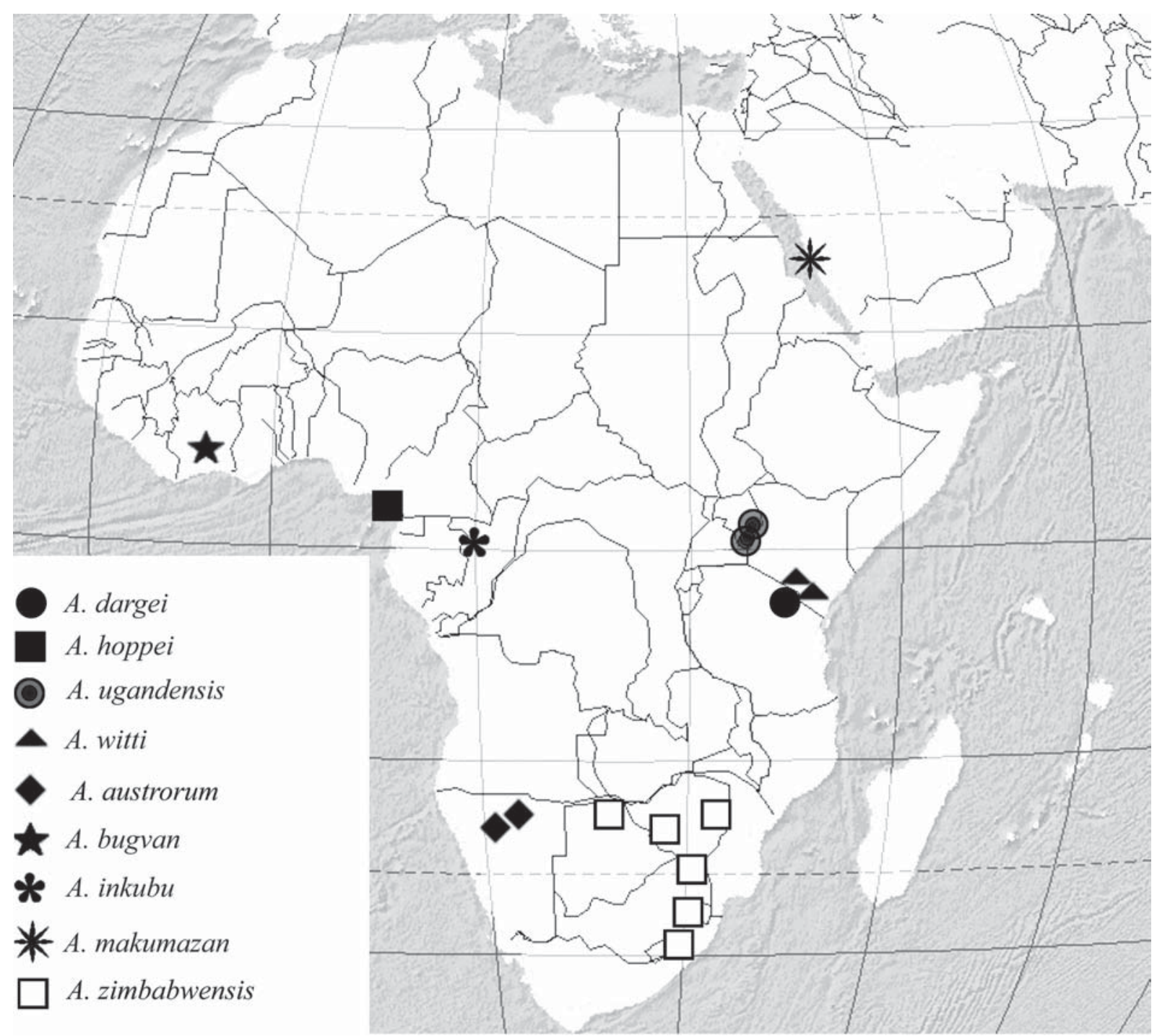

Fig. 1. Distributional map of Afrikanetz.

Рис. 1. Карта распространения видов рода Afrikanetz. 

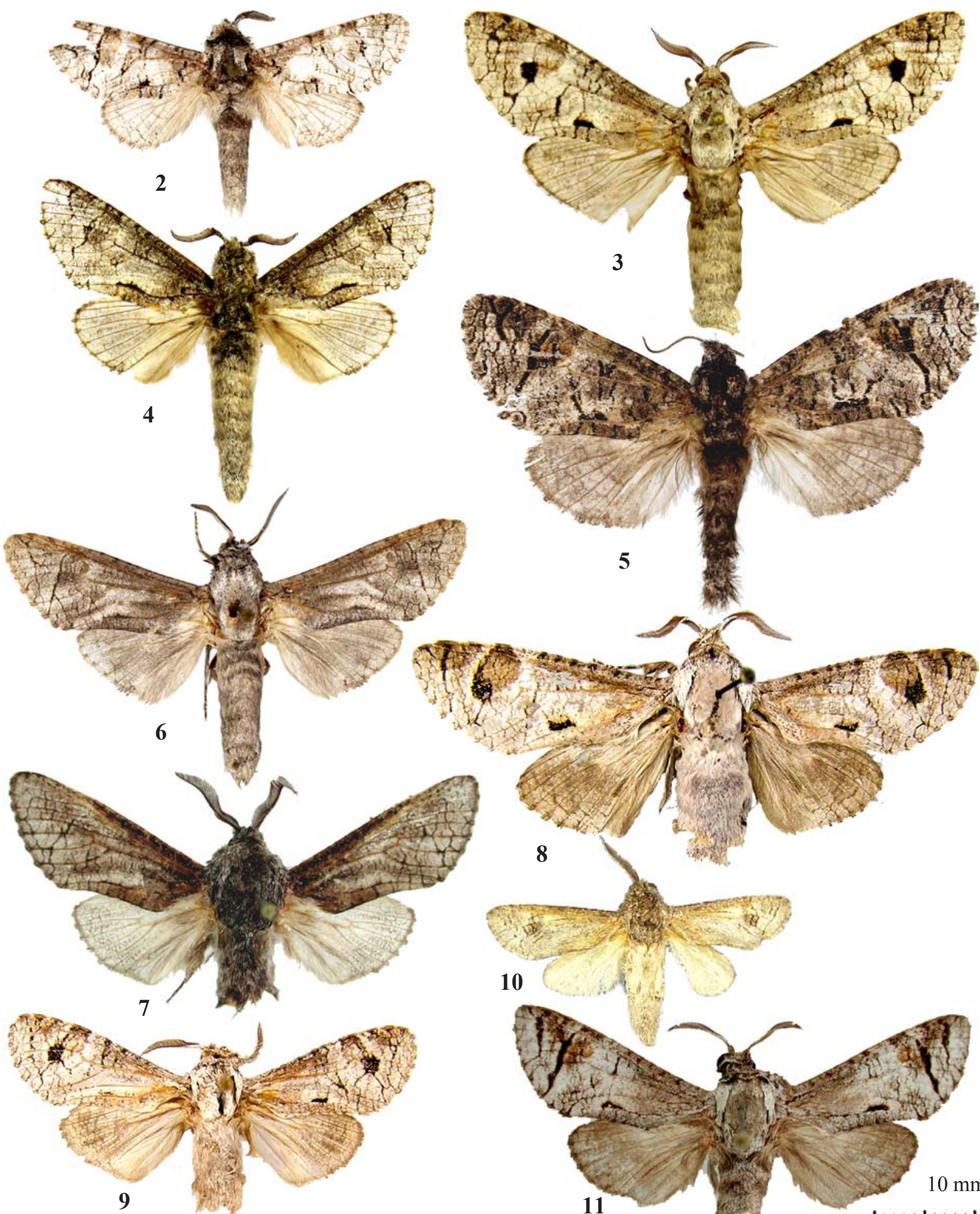

3

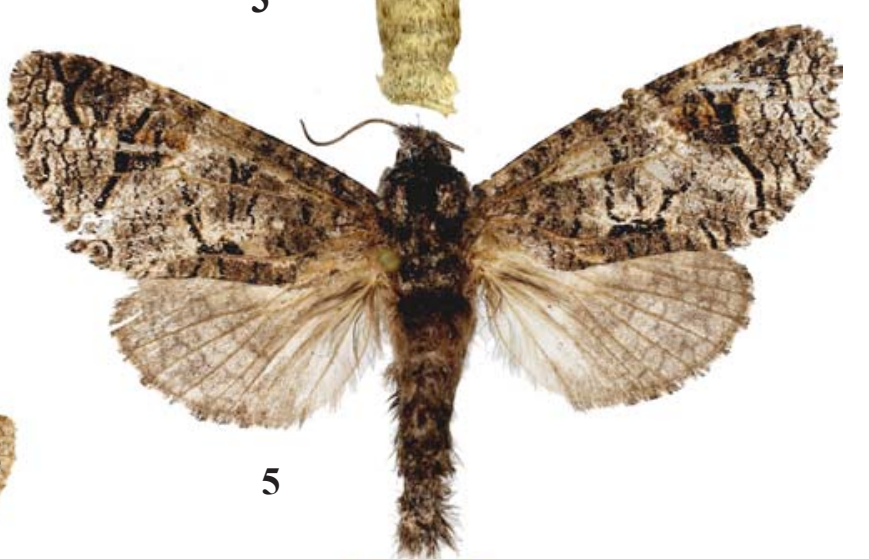


wing pale grey, with thin black transverse strokes, poorly developed brownish field in discal area (medially), grey field basally. Fringe on fore wing mottled, grey at veins and white between veins. Hind wing pale grey, with poorly expressed transverse grey strokes, fringe grey unicolorous.

Genitalia (Fig. 12). Uncus long, tapered, apically sharp; gnathos arms long, of medium thickness; gnathos covered with spikes, consists of two well noticeable halves interconnected with a membrane; valve apically semi-circular, membranous, costal edge strongly serrated in distal third, with three transverse ribs on inner surface; transtilla process uncinate, thin, apically sharp; juxta robust, trapezoidal, with robust cylindrical lateral processes; saccus robust, semicircular; phallus long, equal to valve in length, slightly curved in medium third, vesica aperture in dorso-apical position, takes $1 / 3$ of phallus in length, robust double dentiform process on vesica aperture edges; vesica without cornuti.

Female unknown.

DIAGNOSIS. The new species differs from the other species of the genus externally, by the pale grey color of the wings and by the poorly expressed discal spot, and in the male genitalia, by the well developed double dentiform process on the vesica aperture edges.

ETYMOLOGY. The new species is named after Philippe Darge (1933), a well-known French diplomat and an amateur entomologist who gathered enormous butterfly collections in Tanzania including this new species.

\section{Afrikanetz hoppei Yakovlev, sp.n.} Figs 3, 13.

MATERIAL. Holotype $\sigma^{7}$, Guinea Equatorial, Isla de Bioko,

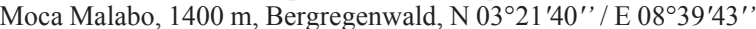
15-21.01.2004, leg. H. Hoppe (MSW, GenPr MSW 2015/19-Coss).

DESCRIPTION. Male. Length of fore wing $21 \mathrm{~mm}$. Antenna bipectinate. Crest processes 4 times longer than antenna rod diameter. Tegulae and patagia pale grey. Fore wing pale grey with rather thick reticulated pattern of thin dark grey lines in postdiscal and submarginal areas, well expressed round dark spot with clear borders in discal area, black elongated stroke along vein $\mathrm{A} 1+2$ in discal area. Fringe on fore wing mottled, grey at veins and white between veins. Hind wing pale grey, with poorly expressed transverse grey strokes, fringe grey unicolorous.

Genitalia (Fig. 13). Uncus relatively short, thick, apically rounded; gnathos arms thick, of medium length; gnathos small, covered with fine spikes; valve relatively wide, apically semicircular, membranous, three ribs on inner surface, the most pronounced of which is the middle one; transtilla process long, curved, uncinate, apically sharp; juxta robust, with leaf-like lateral processes; saccus robust, elongated along the axis; phallus long, equal to valve in length, slightly curved on border of distal and medial thirds, vesica aperture in dorso-apical position, equals to $1 / 3$ of phallus in length, double dentiform process on vesica aperture edges; vesica without cornuti.

Female unknown.

DIAGNOSIS. The new species externally resembles $A$. bugvan, from which it differs by the absence of the brown spot in the postdiscal area of the fore wing. It also differs from the other species of the genus by the short and robust uncus.

ETYMOLOGY. The new species is named after Herni Hoppe (1961-2011), a well-known German amateur entomologist who has collected this species.

\section{Afrikanetz ugandensis Yakovlev, sp.n.}

Figs 4-5, 14.

MATERIAL. Holotype $\sigma^{7}$, Uganda, Napak Mt., Moroto, 01.2008 (MSW, GenPr MSW 2015/18-Coss). Paratype 1 \%, Uganda, Eastern
Region, Mt. Elgon, Umg. Bukwo, N01²3.402' / E 3471.680', 10.01.2011, leg. Harald Sulak \& Tom Kolb (MWM, GenPr Heterocera MWM: 32.873)

DESCRIPTION. Male. Length of fore wing $15 \mathrm{~mm}$. Antenna bipectinate. Crest processes 3 times longer than antenna rod diameter. Tegulae and patagia grey. Fore wing grey, with poorly expressed reticulated pattern and thin black bands in submarginal and postdiscal areas; poorly expressed blurred brown spot in discal area, black elongated stroke along vein $\mathrm{A} 1+2$ in discal area. Fringe on fore wing mottled, grey at veins and white between veins. Hind wing pale grey, with poorly expressed grey sputtering, anal area pale brown, fringe grey, unicolorous.

Male genitalia (Fig. 14). Uncus long, triangle, apically sharp; gnathos arms of medium thickness; gnathos compact, densely covered with spikes; valve apically lanceolate, membranous, tubercle on costal edge in the zone of transition of sclerotized (proximal) part to membranous (distal) part, three blurred ribs on inner surface of valve, the most pronounced of which is closest to the top; transtilla process short, uncinate, curved in medium third; juxta robust, with lateral processes diverged to sides; saccus of medium size, semi-circular; phallus shorter than valve, thick, slightly curved on border of distal and medial thirds, vesica aperture in dorso-apical position, equals to $1 / 3$ of phallus in length, edges smooth; vesica without cornuti.

Female bigger than male, length of fore wing $20 \mathrm{~mm}$. Antenna bipectinate, processes very short, almost equal to antenna rod diameter. Tegulae and patagia pale brown. Fore wing wider than that of male, colored more contrast, dark elements significantly more expressed, well developed black bands in submarginal, postdiscal and discal areas, bright brown spot in discal area. Hind wing pale grey, with poorly expressed grey strokes.

Female genitalia (Fig. 15). Papillae anales narrow, cylindrical; oblique notches on lateral surfaces of ovipositor; posterior apophyses twice longer than anterior ones; ostium poorly submerged, oval; antrum cup-like, sclerotized; ductus short, wide; bursa long, bag-like.

DIAGNOSIS. The new species is well distinguished in the male genital structure — the blurred ribs on the valve inner surface and the completely reduced double dentiform process on the vesica aperture edges.

ETYMOLOGY. Toponym, by the country name.

\section{Afrikanetz witti Yakovlev, sp.n.}

Fig. 6, 16.

MATERIAL. Holotype $\sigma^{7}$, Kenya, Kibwezi, 700 m, 10-20.06. 1996, leg. Dr. Politzar (MWM; GenPr Heterocera: 32863). Paratypes:

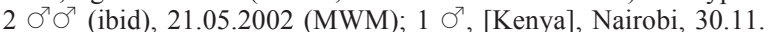
1991, leg. Dr. Politzar (MWM)

DESCRIPTION. Male. Length of fore wing 18-19 mm (holotype $18 \mathrm{~mm}$ ). Antenna bipectinate. Crest processes 3 times longer than antenna rod diameter. Tegulae and patagia grey. Fore wing grey, with poorly expressed reticulated pattern in submarginal and postdiscal areas; light areas with blurred borders in discal area, poorly expressed grey-brown spot in discal area. Fringe on fore wing mottled, dark grey at veins, paler between veins. Hind wing pale grey, with poorly expressed grey sputtering, anal area pale brown, fringe grey, unicolorous.

Male genitalia (Fig. 16). Uncus long, apically sharp, gnathos arms thick, of medium length; gnathos well structured, covered with fine spikes; valve apically semi-circular, membranous, costal edge curved; on inner surface in the zone of transition of sclerotized part to membranous part, four transverse ribs, the proximal one of which extends from costal edge to the middle of valve; the next, closest to apex, very short; two longest distal crests fused into one crest near saccus; transtilla process relative- 


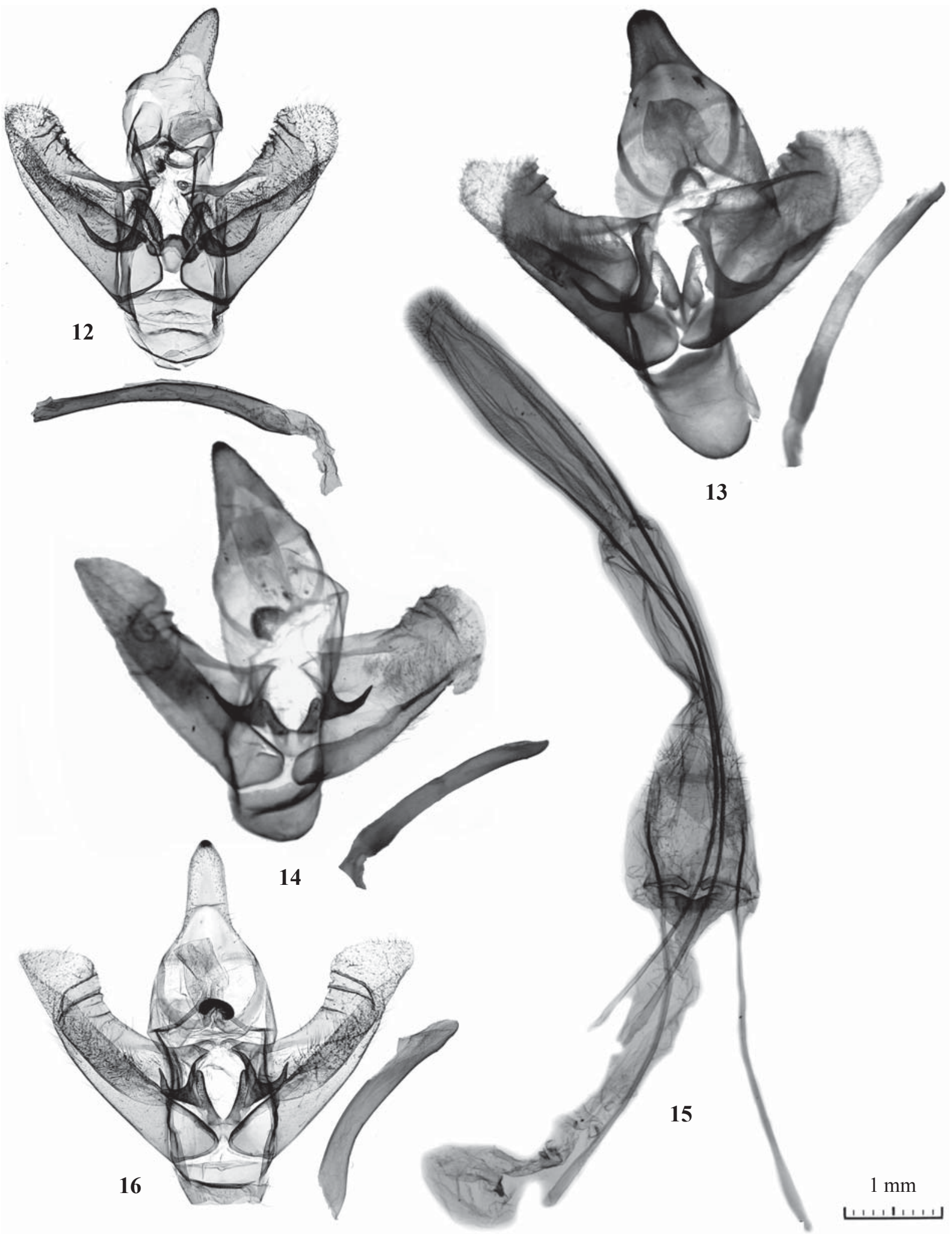

Figs 12-16. Genitalia of Afrikanetz: $12-$ A. dargei Yakovlev sp.n., $0^{7}$, holotype (MWM); $13-$ A. hoppei Yakovlev sp.n., $0^{7}$, holotype (MSW); $14-$ A. ugandensis Yakovlev sp.n., ${ }^{`}$, holotype (MSW); $15-$ A. ugandensis Yakovlev sp.n.,, , paratype (MWM); $16-A$. witti Yakovlev sp.n., $O^{\text {T, }}$, holotype (MWM).

Рис. 12-16. Гениталии Afrikanetz: 12 - A. dargei Yakovlev sp.n., $0^{7}$, голотип (MWM); 13 - A. hoppei Yakovlev sp.n., $0^{7}$, голотип (MSW); 14 - A. ugandensis Yakovlev sp.n., O’ $^{\top}$ голотип (MSW); 15 - A. ugandensis Yakovlev sp.n., , , паратип (MWM); 16 - A. witti Yakovlev sp.n., О', голотип (MWM). 
ly short, strongly curved in distal third, apically sharp; juxta robust, with long lateral processes; saccus semi-circular, phallus short (2/3 of valve in length), thick, slightly curved on border of proximal and medial thirds, vesica aperture in dorso-apical position, takes $1 / 2$ of phallus in length, double dentiform process on vesica aperture edges; vesica without cornuti.

Female unknown.

DIAGNOSIS. The new species differs from the other species of the genus by the almost unicolorous grey color of the wings, the relatively short phallus, and the short transtilla processes sharply curved in distal third.

ETYMOLOGY. The new species is named after Thomas J. Witt (1947-2019), the founder of the largest private collection of Lepidoptera - the Museum of Thomas Witt (Munich, Germany).

Catalog of the genus Afrikanetz Yakovlev, 2009 Afrikanetz Yakovlev, 2009: 358

Type species (by the original description) - Afrikanetz inkubu Yakovlev, 2009.

Afrikanetz austrorum (Mey, 2017) comb.n. (Fig. 7)

Camellocossus austrorum Mey, 2017: 221. Type locality: Namibia, Etosha National Park, Camp Halali. Type material: holotype (MNKB). Distribution: Namibia (Oshikoto and Kunene Prov.)

NOTE. On a small series from Namibia, Mey [2017] described a new species, Camellocossus austrorum, and noted that "The species is tentatively placed in Camellocossus Yakovlev, 2011." The structure of antenna (bipectinate) and male genitalia (ribs on the valve inner surface) indicates that this species belongs to the genus Afrikanetz.

Afrikanetz bugvan Yakovlev, 2009 (Fig. 8)

Afrikanetz bugvan Yakovlev, 2009: 359. Type locality: C. de Ivoire, Lamto. Type material: holotype (MRAC). Distribution: Coted'Ivoire.

Afrikanetz dargei Yakovlev, sp.n.

Type locality: Tanzania, Arusha Region, Mt. Meru. Type material: holotype (MWM). Distribution: Tanzania.

\section{Afrikanetz hoppei Yakovlev, sp.n.}

Type locality: Guinea Equatorial, Isla de Bioko, Moca Malabo. Type material: holotype (MSW). Distribution: Guinea Equatorial (Bioko Island).

Afrikanetz inkubu Yakovlev, 2009 (Fig. 9)

Afrikanetz inkubu Yakovlev 2009: 359. Type locality: Congo, Odzala N.P. Type material: holotype (MWM). Distribution: Congo Republic.

\section{Afrikanetz makumazan Yakovlev, 2009 (Fig. 10)}

Afrikanetz makumazan Yakovlev 2009: 359. Type locality: Arabia, Jedda. Type material: holotype (NHMUK). Distribution: Saudi Arabia.

\section{Afrikanetz ugandensis Yakovlev, sp.n.}

Type locality: Uganda, Napak Mt., Moroto. Type material: holotype (MSW). Distribution: Uganda.

\section{Afrikanetz witti Yakovlev, sp.n.}

Type locality: Kenya, Kibwezi. Type material: holotype (MWM) Distribution: Kenya.

Afrikanetz zimbabwensis (Mey, 2017) comb.n. (Fig. 11)

Coryphodema zimbabwensis Mey 2017: 221. Type locality: Zimbabwe, Aberfoyle, Monde Valley. Type material: holotype (TMSA). Distribution: Zimbabawe (Manikalend Prov.), Republic of Southern Africa (KwaZulu-Natal, Mpumalanga, Limpopo Prov.). ADDITIONAL MATERIAL. $2 \sigma^{7}$, Botswana, Chobe Rapids Kasana, 14-15.09.1974 (NHMZ); 1 \%', S. Rodes.[ia], Bulawayo, 25.09.1976, E. Pinhey leg. (NHMZ); 1 \%", Richmond, Bulawayo, 09.1976, R.F. Koster (NHMZ); $1 \sigma^{7}$, Suburbs. Bulawayo, 1.10.1977, E. Pinhey leg. (NHMZ); 1 ○', Bulawayo, Lak Bissen, 5.03.1978 (NHMZ).

NOTE. On a series from RAS and Zimbabwe, Mey [2017] described Coryphodema zimbabwensis, moreover, in the description he noted his uncertainty about attributing the new species to the genus Coryphodema Felder, 1874 (type species - Coryphodema capensis Felder, 1874). The external characters and male genital structure (the robust ribs on the valve inner surface) indicate the affiliation of $C$. zimbabwensis to the genus Afrikanetz.

Acknowledgments. The authors expresses sincere gratitude to the colleagues who helped in working with the material: Thomas Witt $\uparrow$, Harald Sulak (Munich), Didier Van den Spiegel, Alice Buset (Tervuren), Martin Krüger (Pretoria), Moira Fitzpatrick (Bulawayo) and Manfred Ströhle (Weiden). We are also thank Geoff Martin (London) and NHMUK Council of Trustees for the kind permission to publish the images of the type specimens deposited in the museum, and A. Bidzilya (Kiev) for his assistance in making the permanent preparations. The authors are grateful to Anna Ustjuzhanina (Tomsk) and Boris Kondratieff (Fort Collins) for language improvements.

\section{References}

Mey W. 2015. Revision of the genus Arctiocossus Felder, 1874 and allied genera (Lepidoptera: Cossidae: Cossinae) // Annals of the Ditsong National Museum of Natural History. Vol.5. P.28-55.

Mey W. 2016. A taxonomic and faunistic study of the Cossidae of southwestern Africa (Lepidoptera: Cossoidea) // Annals of the Ditsong National Museum of Natural History. Vol.6. P.146-198.

Mey W. 2017. Corrections and additions to the Cossidae of southern Africa (Lepidoptera: Cossoidea) // Entomologische Zeitschrift. Vol.127. No.4. P. 218-222.

Yakovlev R.V. 2009. New taxa of African and Asian Cossidae (Lepidoptera) // Euroasian Entomological Journal. Vol.8. No.3. P.353-361.

Yakovlev R.V. 2011. Catalogue of the Family Cossidae of the Old World // Neue Entomologische Nachrichten. Bd.66. P.1-129

Yakovlev R.V. 2014. Cossidae (Lepidoptera) of Zambia // Check List. Vol.10. No.4. P.724-728. https://doi.org/10.15560/ 10.4.724.

Yakovlev R.V., Dubatolov V.V. 2013. Distribution of CarpenterMoths (Lepidoptera, Cossidae) in the Palaeractic Deserts // Entomological Review. Vol.93. No.8. P.991-1004.

Yakovlev R.V., Lenz J. 2013. On the Fauna of Cossidae (Lepidoptera) of Zimbabwe with description of a new species // Zootaxa. Vol.3718. No.4. P.387-397. https://doi.org/10.11646/ zootaxa.3718.4.8.

Yakovlev R.V., Murphy R.J. 2013. The Cossidae (Lepidoptera) of Malawi with descriptions of two new species//Zootaxa. Vol.3709. No.4. P.371-393.

Yakovlev R.V., Sáfián Sz. 2016. Geraldocossus gen. nov. (Lepidoptera, Cossidae) from Mount Cameroon (West Africa) // Zootaxa. Vol.4114. No.5. P.595-599. https://doi.org/10.11646/ zootaxa.4114.5.8

Yakovlev R.V., Witt Th.J. 2016. Carpenter-Moths (Lepidoptera: Cossidae) of Swaziland, South Africa // Far Eastern Entomologist. Vol.311. P.9-12.

Yakovlev R.V., Witt Th.J. 2017. Four new species of Azygophleps Hampson, 1892 (Lepidoptera, Cossidae, Zeuzerinae) from Africa // Zootaxa. Vol.4303. No.3. P.437-444. https://doi.org/ 10.11646/zootaxa.4303.3.9.

Yakovlev R.V., Witt Th.J. 2019. Cossidae (Lepidoptera) of Burundi (first results) // Ecologica Montenegrina. Vol.20. P.105-109. 